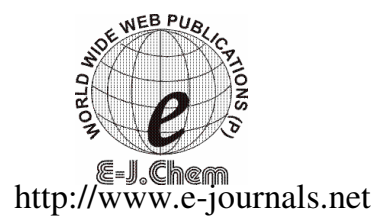

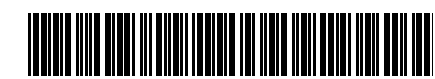

ISSN: 0973-4945; CODEN ECJHAO

E-Journal of Chemistry 2010, 7(S1), S157-S162

\title{
The Geoaccumulation Index of Some Heavy Metals in Al-Hawizeh Marsh, Iraq
}

\author{
M. J. S. AL-HAIDAREY, F M. HASSAN ${ }^{\S *}$, \\ A R A. AL-KUBAISEY ${ }^{\S}$ and A A Z. DOUABUL \\ College of Pharmacy, University of Kufa, Najaf, Iraq \\ ${ }^{\S}$ Department of Biology, College of Science for Women \\ University of Baghdad, Jadirya P.O. Box 47131, Baghdad, Iraq \\ ${ }^{\#}$ Canada-Iraq Marshlands Initiative \\ Department of Earth and Environmental Sciences, University of Waterloo200 \\ University Avenue West, Waterloo, Ontario, Canada N2L 3G1 \\ fik.has@gmail.com
}

Received 6 March 2010; Accepted 20 May 2010

\begin{abstract}
Heavy metals have a great ecological significance due to their toxicity and accumulative behavior. The geoaccumulation index $\left(\mathrm{I}_{\text {geo }}\right)$ in 10 stations in AlHawizeh Marsh, (i.e Al-Adaim (I \& II), Um Al-Neaj (I \& II), Um-Awarded, North Al-Soudah, South Al-Soudah, Al-Beda, Lissan Ejerdah and Majnoon) were calculated in this article. The sediment pollution was investigated by following the concentration of six heavy metals ( $\mathrm{As}, \mathrm{Cd}, \mathrm{Cr}, \mathrm{Co}, \mathrm{Cu}$ and $\mathrm{Pb}$ ). Inductively coupled plasma mass spectroscopy (ICPMS) was used for analysis. According to the geoaccumulation index $\left(\mathrm{I}_{\text {geo }}\right)$ the results of all the 10 stations were analyzed and discussed in detailed.
\end{abstract}

Keywords: Gepaccumulation index, Heavy metals, Pollution, Mesopotamian marshs, Al-Hawizeh Marsh, Iraq.

\section{Introduction}

The Mesopotamian marshland in southern Iraq, has enormous ecological and environmental importance. The Iraqi marshlands are one of the finest and most extensive natural wetland ecosystems in Europe and western Asia ${ }^{1}$. Around $85 \%$ of the Mesopotamian Marshlands have been lost mainly as a result of drainage and damming ${ }^{2}$. Currently, restoration by reflooding of drained marshes is proceeding and the ecological effects of this massive water diversion need elaborated research. Al-Hawizeh and its associated marshes are considered to be the largest within the mesopotamian marshes ${ }^{3}$. Various researches from different universities of Iraq have been studying the flora and fauna and furthermore limnology and the productivity of the Mesopotamian marshes ${ }^{4,5}$. 
Heavy metal contamination is widespread in different Iraqi aquatic system ${ }^{6-9}$. On a weight per square meter basis, the uppermost superficial sediments constitute the largest heavy metals reservoir in aquatic systems. Once accumulated in sediments, the metals continue to pose a threat to aquatic life due to re-suspension into the water column from geochemical re-cycling ${ }^{10,11}$, accumulation in benthic fauna that feed on sediments and through food chain transfer, including organo elements ${ }^{12}$.

To gauge the degree of anthropogenic influence on heavy metals concentration in the sediments used $\mathrm{I}_{\text {geo }}$. Generally, the $\mathrm{I}_{\text {geo }}$ consists of 7 grades or classes (Table 1).

Table 1. The degree of metal pollution in terms of seven enrichment classes ${ }^{14}$

\begin{tabular}{ccl}
\hline $\mathrm{I}_{\text {geo }}$ Value & $\mathrm{I}_{\text {geo }}$ Class & designation of sediment quality \\
\hline$>5$ & 6 & extremely contaminated \\
$4-5$ & 5 & strongly to extremely contaminated \\
$3-4$ & 4 & strongly contaminated \\
$2-3$ & 3 & moderately to strongly contaminated \\
$1-2$ & 2 & moderately contaminated \\
$0-1$ & 1 & uncontaminated to moderately contaminated \\
$0<$ & 0 & Uncontaminated \\
\hline
\end{tabular}

The $\mathrm{I}_{\text {geo }}$ was calculated using Muller ${ }^{13}$ and Abrahim \& Parker $^{14}$ method as follows: $I_{\text {geo }}=\log _{2}\left([\right.$ sediment $] / 1.5^{*}$ [reference sample $\left.]\right)$

The factor 1.5 is introduced to minimize the effect of possible variations in the background values which might be attributed to lithologic variations in the sediments. According to Bradl ${ }^{15}$ the reference samples were As: 13, Cd: 0.3, Co: 20, Cr: 100, Pb: 20 and Cu: $50 \mu \mathrm{g} / \mathrm{g}$.

\section{Study area}

Al-Hawizeh Marsh lies between $31^{\circ} 00^{\prime}-31^{\circ} 45^{\prime} \mathrm{N}, 47^{\circ} 25^{\prime}-47^{\circ} 50^{\prime} \mathrm{E}$ (Figure 1). The Iranian section of the marshes is known as Al-Azim , Marsh where it is fed primarily by the Karkeh River. In Iraq, this marsh is largely fed by two main distributaries departing from the Tigris River near Amarah city, known as Al-Musharah and Al-Kahla.

Ten stations in Al-Hawizeh were selected in this study. Two stations in Al-Adaim, One station in Al-Soudah north, Two stations in Um El-Nia'j, One station in Al-Baida, One station in Um Al-Wared marsh, One station in the Al-Soudah south marsh, One station in the Majnoon marsh and One station in the Lissan Ejerdah (Figure 1). The exact position of each sampling station was recorded using global positioning system (GPS, model Geko 201/ Taiwan).

\section{Experimental}

Sediment samples were collected from the studied stations using an Ekman Grab sampler $(15.2 \times 15.2 \mathrm{~cm})$. Samples were collected in May, Aug and Dec 2006. After retrieval of the sampler, the water was allowed to drain off, avoiding, disturbing the surface layer of the samples preserved using nylon zipper-sealed bags $(17.7 * 20.3 \mathrm{~cm})$. As soon as the samples were retrieved, placed in an ice box until reaching the lab they placed in plastic bags before freezing ${ }^{16}$. Before analysis, the sediment samples were drying in an oven (Model: Memmert S40) at $50^{\circ} \mathrm{C}$ for over night, grinded finely in an agate mortar and sieved through a $63 \mu \mathrm{m}$ plastic sieve.

Analysis of heavy metals was preformed according to Radojevic and Bashkin ${ }^{17}$, using the high quality concentrated $(70 \% \mathrm{w} / \mathrm{v})$ nitric acid, hydrogen peroxide $(35 \%)$ and hydrochloric acid (38\%) for sediments digestion (using digestion system model: Soil Digester 1015). In SGS Lakefield Research Limited Lab/ Lakefield-Ontario, ICPMS (Model: ICPMS - Varian MS 820) standards for elements were used in specimen analysis. 


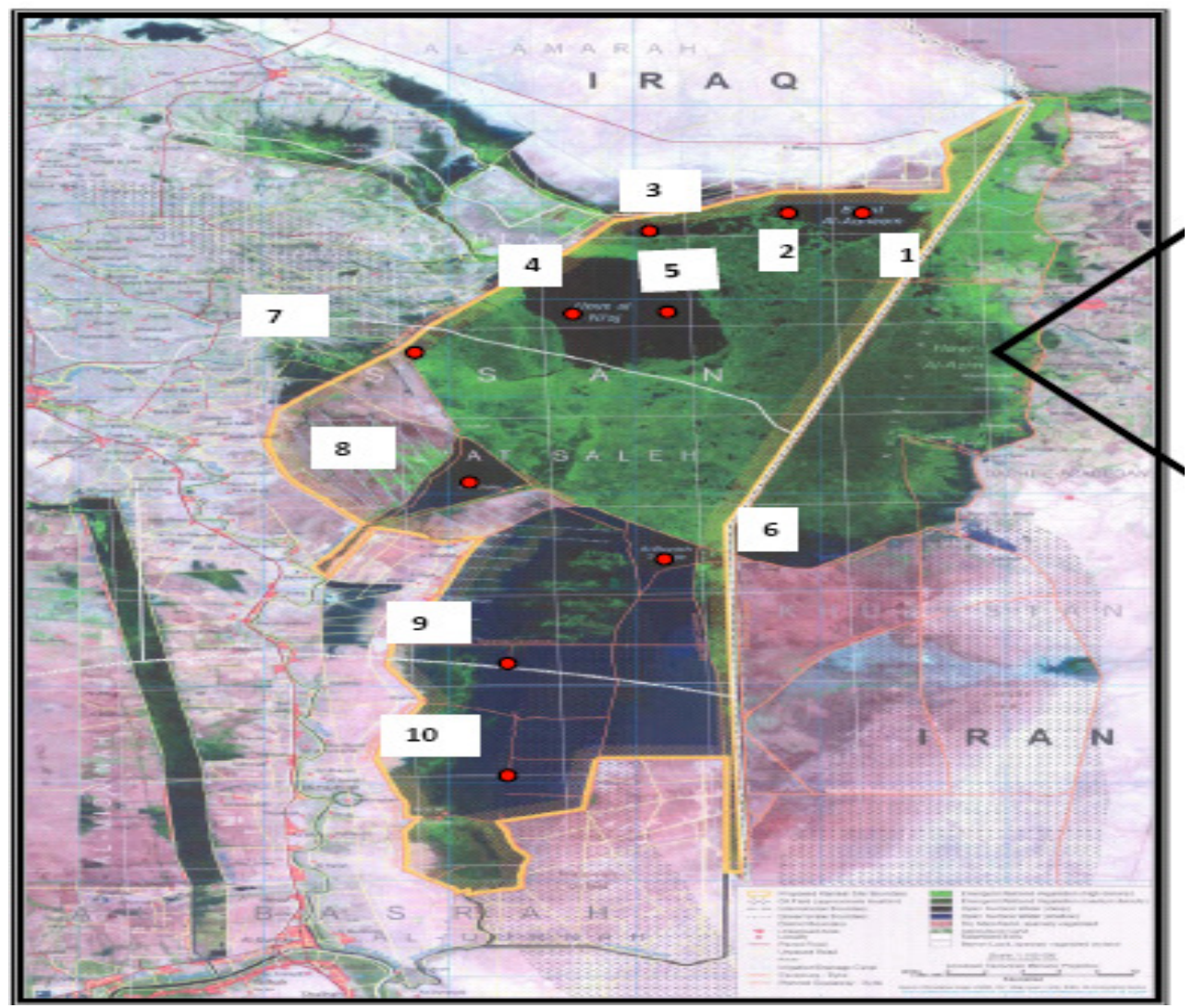

Figure 1. The study stations in Al-Hawizeh Marsh. Al-Adaim-I \& II (1 and 2), Al-Soudah North (3), Um-El-Nia'j-I \& II $(\mathbf{4}, \mathbf{5})$ and Al-Baida (6), Um Al- Wared (7), Al-Soudah South (8), Majnoon (9) and Lissan Ejerdah (10).

\section{Results and Discussion}

Many studies in different region from the world have used the sediments of the wetlands as indicator for pollution ${ }^{18,19}$. The highest concentrations of $\mathrm{Cu}, \mathrm{Pb}$ and $\mathrm{Cd}(316,4434,109 \mu \mathrm{g} / \mathrm{g}$ respectively) were recorded in Um-El.Nia'j-I station (Table 2). This station didn't exposure for dried processes, so it has a lot of sediments with high concentrations of metals, the main water sources of Um El-Nia'j are Al-Zubair and Umm Al-Toos Rivers and large villages are established near this marsh such as Abu Khassaf village.

The highest concentration of $\mathrm{Cr}$ was recorded in Al-Adaim station $(818 \mu \mathrm{g} / \mathrm{g})$, this station also didn't exposure for dried processes. During the flooding season the extra surface water runs from the Al-Sanna'f marsh, the higher elevation to Al-Hawizeh via AlFaisal channel.

The highest levels of Co and As were recorded in Al-Soudah South and Um-Wared stations (20892, $3353 \mu \mathrm{g} / \mathrm{g}$ respectively). These stations had dried and the ground was used for crops culturing, in addition to different military activities before re-flooding (Table 2).

The present study revealed that the lowest values of $\mathrm{Cr}, \mathrm{Pb}, \mathrm{Cu}, \mathrm{Co}$, As and $\mathrm{Cd}$ were recorded in completely dried marshes (Um-Wared, Um-El.Nia'j stations and Lissan Ejerdah), 
may be due to many reasons such as the newly sediment's surface, low accumulated metals in the sediment particulates and organisms diversity than northern stations.

Table 2. The mean concentration (standard deviation) of heavy metals $(\mu \mathrm{g} / \mathrm{g})$ in sediments of Al-Hawizeh Marsh

\begin{tabular}{lcccccc}
\hline \multicolumn{1}{c}{ Stations } & $\mathrm{As}$ & $\mathrm{Cd}$ & $\mathrm{Co}$ & $\mathrm{Cr}$ & $\mathrm{Pb}$ & $\mathrm{Cu}$ \\
\hline Al-Adaim-I & $10292(8633)$ & $36(12)$ & $30(13)$ & $653(45)$ & $2407(156)$ & $234(75)$ \\
Al-Adaim-II & $8078(136)$ & $41(20)$ & $35(14)$ & $818(560)$ & $2154(259)$ & $207(126)$ \\
Um-El.Nia'j-I & $13835(236)$ & $109(60)$ & $92(78)$ & $680(252)$ & $4434(380)$ & $316(92)$ \\
Um-El.Nia'j-II & $75(61)$ & $15(9)$ & $20(13)$ & $332(316)$ & $489(56)$ & $82(46)$ \\
Al-Sudah N. & $1687(267)$ & $28(17)$ & $351(57)$ & $617(544)$ & $511(339)$ & $108(49)$ \\
Um Al-Wared & $1120(188)$ & $32(52)$ & $3353(756)$ & $94(128)$ & $244(31)$ & $67(69)$ \\
Al-Baidah & $354(407)$ & $30(18)$ & $44(51)$ & $320(32)$ & $249(217)$ & $100(36)$ \\
Al-Sudah South & $20892(861)$ & $98(11)$ & $49(31)$ & $243(142)$ & $2127(1404)$ & $142(0.32)$ \\
Lesan Ejerdah & $3833(337)$ & $16(0.84)$ & $46(49)$ & $243(160)$ & $1084(480)$ & $86(29)$ \\
Majnon & $9229(922)$ & $20(17)$ & $52(45)$ & $191(130)$ & $2325(2294)$ & $127(99)$ \\
\hline
\end{tabular}

The $\mathrm{I}_{\mathrm{geo}}$ classes for 6 studied heavy metals for each station are listed in Table 3 . The $\mathrm{I}_{\text {geo }}$ values revealed that nearly Um-El.Nia'j-II and Um Al-Wared for Co and Cr respectively fell into class 0 (Figure 2).

Table 3. The results of Geochemical Index calsses.

\begin{tabular}{lcccccc}
\hline \multicolumn{1}{c}{ Station } & $\mathrm{As}$ & $\mathrm{Cd}$ & $\mathrm{Co}$ & $\mathrm{Cr}$ & $\mathrm{Pb}$ & $\mathrm{Cu}$ \\
\hline Al-Adaim-I & 3 & 2 & 1 & 1 & 2 & 1 \\
Al-Adaim-II & 3 & 2 & 1 & 1 & 2 & 1 \\
Um-El.Nia'j-I & 3 & 3 & 1 & 1 & 3 & 1 \\
Um-El.Nia'j-II & 1 & 2 & 0 & 1 & 2 & 1 \\
Al-Soudah North & 2 & 2 & 2 & 1 & 2 & 1 \\
Um Al-Wared & 2 & 2 & 3 & 0 & 1 & 1 \\
Al-Baida & 2 & 2 & 1 & 1 & 1 & 1 \\
Al-Soudah South & 4 & 3 & 1 & 1 & 2 & 1 \\
Lissan Ejerdah & 3 & 2 & 1 & 1 & 2 & 1 \\
Majnoon & 3 & 2 & 1 & 1 & 2 & 1 \\
\hline
\end{tabular}

The $\mathrm{I}_{\text {geo }}$ values for $\mathrm{Cu}, \mathrm{Cr}$ (except Um Al-Wared was in class 0) and Co (except UmEl.Nia'j-II, Um Al-Wared and Al-Soudah south stations were in class 0,3 and 2 respectively) were $>0$ and $<1$ for all stations. This indicates that the sediments in these stations are uncontaminated to moderately contaminate by these metals (Figure 2). The $\mathrm{I}_{\text {geo }}$ values for $\mathrm{Cd}$ in all stations (except in Um-El.Nia'j-I and Al-Soudah S were in class 3) are greater than 1 (moderately contaminated).

The $\mathrm{Pb} \mathrm{I}_{\text {geo }}$ values varied mostly, ranging from 0.911-2.17 (Figure 2). The most of stations fell in class 2 (moderately contaminated), except Um-El.Nia'j-I (in class 3), Um AlWared and Al-Baida are fall in class 1.

For the As metal, the Al-Adaim-I, Al-Adaim-II, Um-El.Nia'j-II, Lissan Ejerdah and Majnoon were found to contain similar pollution levels (fell in class 3), Al-Soudah South fell in strongly contamination class 4 , while the other semidried marshes stations (Al-Soudah South Um-El.Nia'j-II, Um Al-Wared Al-Baida) were less contamination and fell in class 2. 


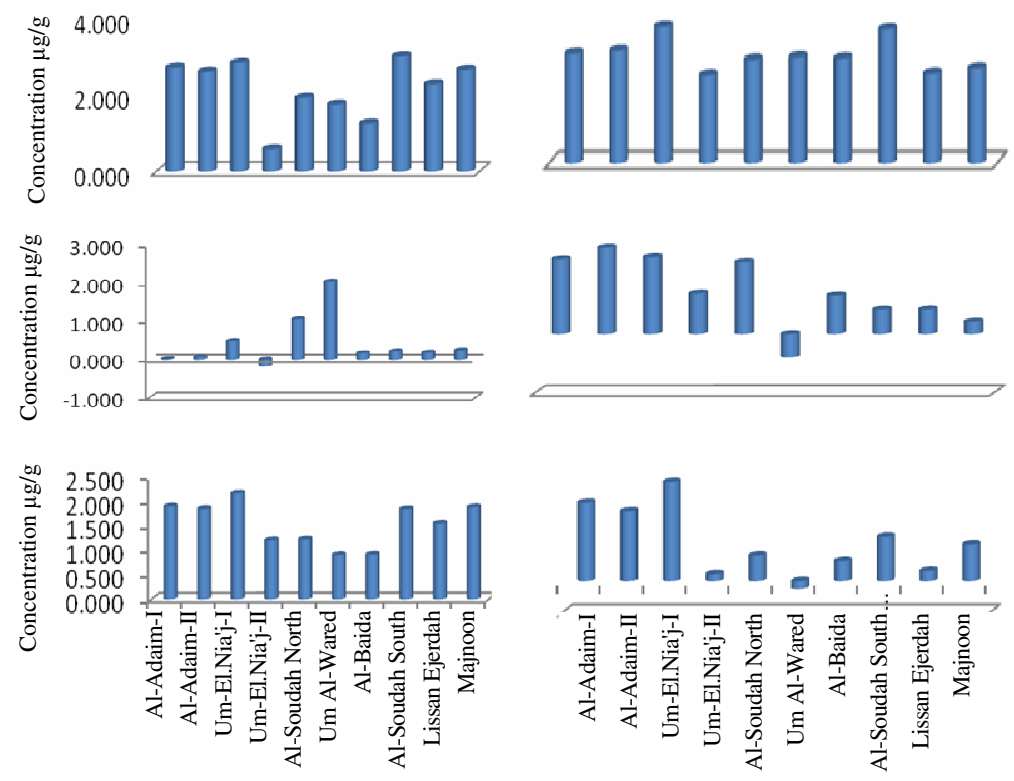

Figure 2. The geochemical index of studied heavy metals in Al-Hawizeh Marsh during the study period

\section{Conclusion}

The sediments of Al-Hawizeh Marshes were suffering from moderately to strongly contaminate with the studied heavy metals according to $\mathrm{I}_{\text {geo }}$ values. The Al-Soudah South is suffering strongly from As metal and moderately from $\mathrm{Cd}$. Other stations were unpolluted with $\mathrm{Co}, \mathrm{Se} \& \mathrm{Cu}$ while $\mathrm{Um} \mathrm{Al}-\mathrm{Wared}$ and $\mathrm{Al}$-Baidah stations were unpolluted with $\mathrm{Pb}$ metal.

\section{References}

1. Evans M I, The ecosystem; Nicholson E, Clark P, Eds., The Iraqi Marshlands: A Human and Environmental Study, London: Politico's, 2002, 201-219.

2. UNEP (United Nations Environment Programme), The Mesopotamian Marshlands: Demise of an Ecosystem Division of Early Warning and Assessment; Nairobi, Kenya, 2002, ISBN: 92-807.

3. Wali M and Al-Hawizeh Marsh, Anthropology Study, M.Sc., Thesis, Baghdad University, Iraq, 1967.

4. Richardson C J and Hussain N A, Bioscience, 2006, 56(6), 477.

5. Hamdan M A, Asada T, Hassan F M, Warner B G, Douabul A, Al-Hilli M R A and Alwan A A, Wetlands, 2010, 30,177-188.

6. Abaychi J K and Douabul A Z, Water Res., 1985, 19, 457-462.

7. Al-Saad H T and Abaychi J K, Marina Mesopotamica, 1995, 10(2), 379-410.

8. Hassan F M, Al-Saadi H A, Al-Haidari M A and Hamed H A, Environ Res Sustainable Develop., 2005, 5, 56.

9. Hassan F M, Saleh M M and Salman J M, E-J Chem., 2010, 7(3), 685-692.

10. Campbell P G C and Tessier A, Ecotoxicology of Metals in the Aquatic Environment: Geochemical Aspects; Newman M C and Jagoe C H Ed., Ecotoxicology: MI Lewis Publishers, Chelsea, 1996, 11-58. 


\section{S162 F M. HASSAN et al.}

11. Ahmet A, Dilek D and Fath D, Water Air Soil Pollut., 2005, 164, 241- 255.

12. MacFarlane G R, Schreider M and McLennan B, Arch Environ Contam Toxicol., 2006, 51(4), 584-593.

13. Muller G, Umschan., 1979, 79, 778-783.

14. Abrahim G M S and Parker R J, Environ Monit Assess., 2008, 136, 227-238.

15. Bradl H B, Heavy Metals in the Environment. Elsevier Academic Press, 2005.

16. Ryan J, Garabet S, Harmsen K and Rashid A, A Soil and Plant Analysis Manual Adapted for the West Asia and North Africa Region. ICARDA Aleppo, Syria, 1996.

17. Radojevic M and Bashkin V N, Practical Environmental Analysis. Royal Society of Chemistry Cambridge, 1999.

18. Dilek D and Ahmet A, Ecological Indicators, 2006, 6, 388-393.

19. Syrovetnik K, Malmstrom M E and Neretnieks I, Environ Pollut., 2007, 47(1), 291. 


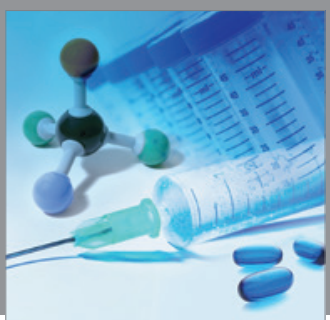

International Journal of

Medicinal Chemistry

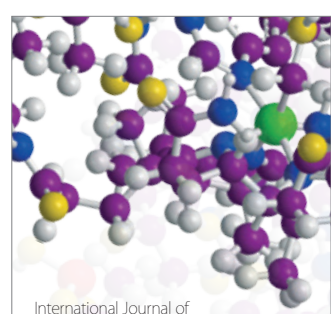

Carbohydrate Chemistry

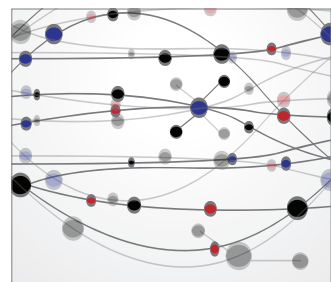

The Scientific World Journal
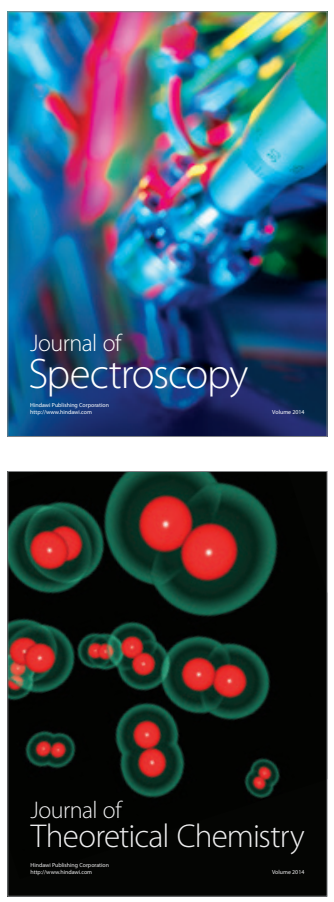
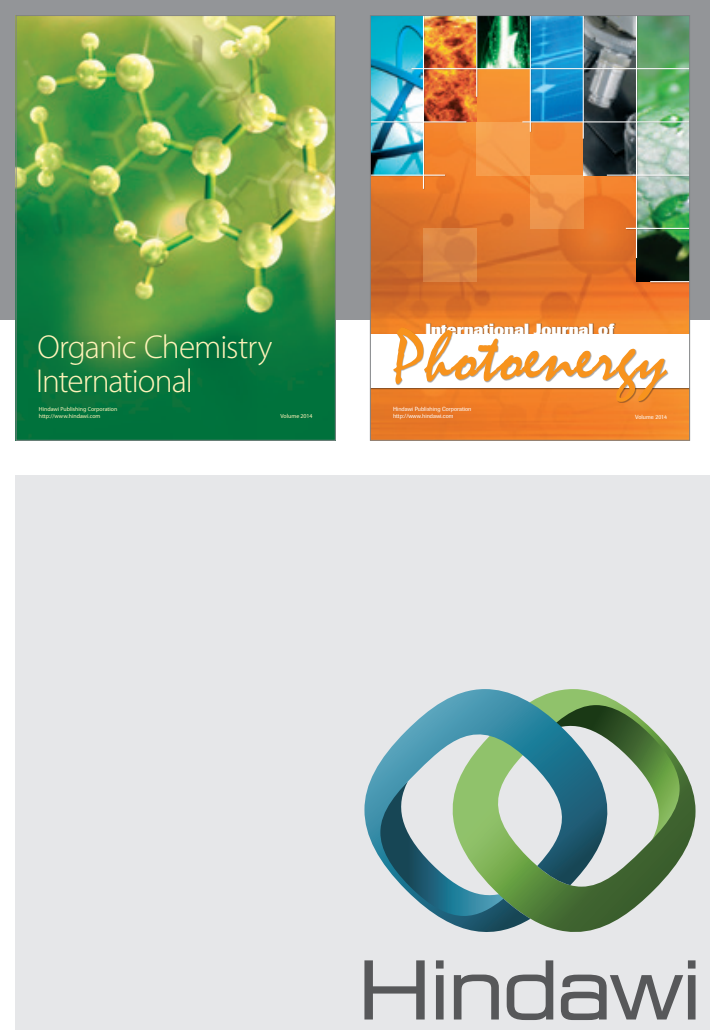

Submit your manuscripts at

http://www.hindawi.com
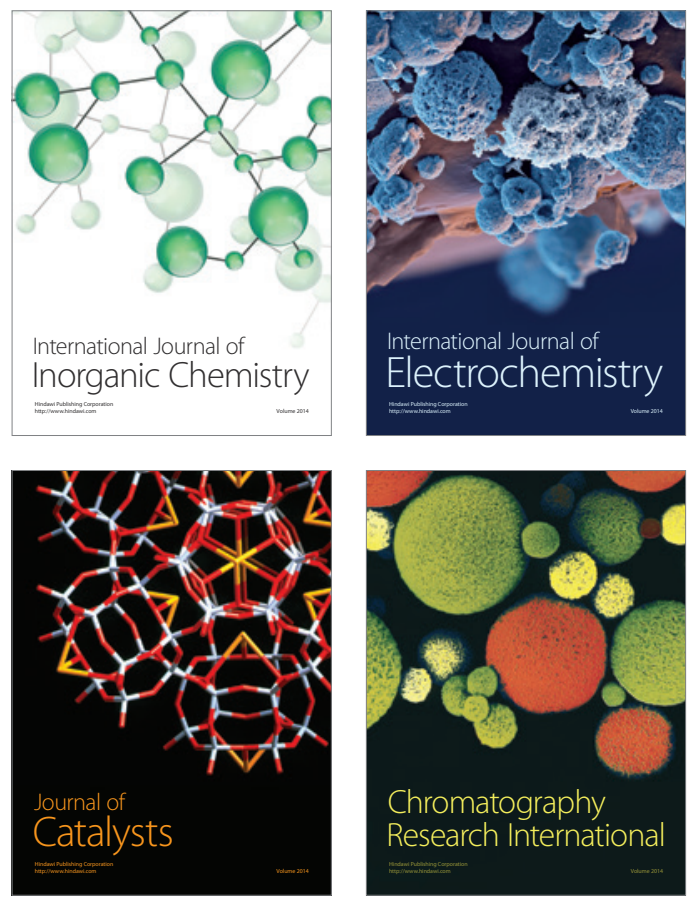
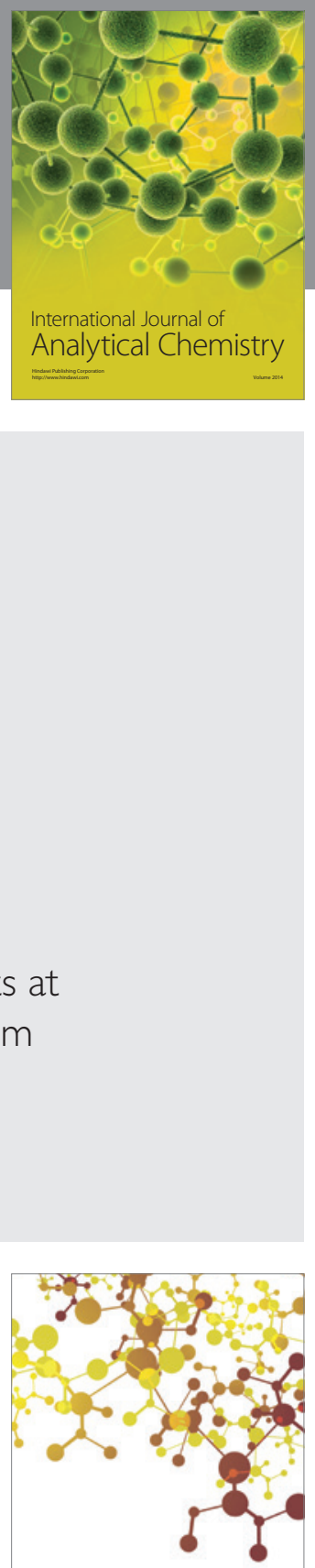

Journal of

Applied Chemistry
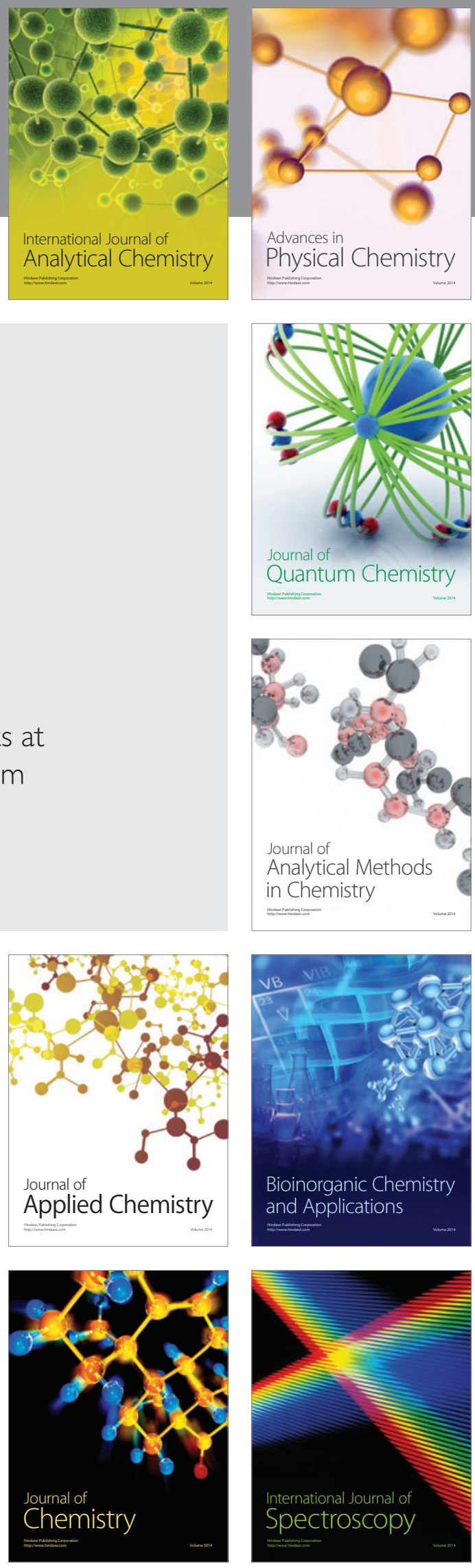